\title{
Formative Assessment System of VR Teaching in English Translation Class
}

\author{
Guifang Wang \\ English School, Zhejiang Yuexiu University, Shaoxing, China \\ Email: 20072026@zyufl.edu.cn
}

How to cite this paper: Wang, G.F. (2022) Formative Assessment System of VR Teaching in English Translation Class. Open Access Library Journal, 9: e8356. https://doi.org/10.4236/oalib.1108356

Received: January 10, 2022

Accepted: February 11, 2022

Published: February 14, 2022

Copyright $\odot 2022$ by author(s) and Open Access Library Inc.

This work is licensed under the Creative Commons Attribution International License (CC BY 4.0).

http://creativecommons.org/licenses/by/4.0/

\section{(c) (i) Open Access}

\begin{abstract}
The emergence of VR technology provides the necessary environment and technical support for individualized English learning. English translation teaching based on VR technology meets the needs of international teaching, and promotes the teaching quality of higher education to achieve nice overtaking opportunities. Formative assessment applies to tracking, monitoring, and assessing students' web-based self-learning process in Business English study in Zhejiang Yuexiu University of Foreign Languages. The assessment results are used to guide students' learning effort, so as to promote their autonomous learning ability, and thus make the assessment process and the teaching process an integrated whole. A formative assessment system for English study is then established based on the research results.
\end{abstract}

\section{Subject Areas}

Higher Education, Language Education

\section{Keywords}

Formative Assessment, Learning Model, English Translation, VR Teaching

\section{Introduction}

VR (virtual reality) technology has become a hot direction of educational informatization research and practical teaching application because of its powerful human-computer interaction means [1]. The application of virtual reality technology in teaching promotes the modernization and informatization of educational means, and is of great significance to the improvement of teaching quality. Virtual simulation teaching can effectively expand the scope and depth of experimental teaching content, extend the time and space of experimental teaching. By contrast, formative assessment, which focuses on study process, provides 
prompt valuable feedback to teachers and students for them to adjust their teaching and learning methods [2]. The author of this paper applies formative assessment to VR English Autonomous Learning in Zhejiang Yuexiu university of Foreign Languages, in the purpose of providing a new method for the integrated combination of teaching and assessment so as to promote Business English teaching and learning.

\section{Literature Review}

\subsection{Formative Assessment}

Formative assessment was originally put forward in 1967 by M. Screven, a famous American assessment expert. This assessment method emphasizes the importance of adjusting the teaching process to realize the teaching goal. Promulgated by the ministry of education of China, college English curriculum requirements define formative assessment as following: "formative assessment is a process and development assessment conducted in the process of teaching [3]. According to the teaching goal, and by using various assessment methods and forms, it tracks the teaching process, gives feedbacks, and promotes the comprehensive development of students."

The formative assessment in Business English teaching not only evaluates students' their daily performance in learning process, but also their achievements, emotions, attitudes and learning strategy [4]. Why should students' web-based autonomous learning be assessed by formative assessment? Because both take constructivism as the theoretical basis, focus on students, and emphasize autonomous learning, cooperative learning and individualized learning.

The roles of students and teachers are changed in the process of formative assessment. As the main body of study, students are also involved in the assessment of the learning process. The student's role changes from one of passive absorber of information to one of active, self-directed learner and evaluator [5]. The role of the teachers is to initiate, organize and supervise the cooperative learning process, and conduct individual tutoring.

\subsection{Application of VR Technology in English Class}

With VR convenient operation and efficient transmission, VR teaching has a good development prospects in interactive teaching, fragmented learning and mobile learning. Nowadays there are few research from the theoretical ground of VR and about how to support mobile learning [6]. It's lack of the systematic analysis of VR learning. Additionally, how to design VR learning courses and teaching activities remains vacant. Yuan Lei, a domestic scholar, taking the course of "basic photography of photography" as an example, analyzes the design and implementation process of blended learning case under the support of VR, and proves that blended learning supported by VR can be effectively promoted in universities. Jiang Hongmei points out VR can be applied to English teaching in the listening, speaking, reading, writing and it has a clear advantage over the tra- 
ditional teaching methods [7].

\section{Empirical Research of Formative Assessment in English Teaching}

\subsection{The Subjects}

The subjects of this study are sophomores of two classes of International Business College in Zhejiang Yuexiu Universities of Foreign Languages. The students of the two classes have similar enrolling scores. Their English capability, study motive, strategy and attitude are average among college students. Therefore, carrying out the research of formative assessment in the two classes will yield result meaningful for making comparison.

\subsection{Research Process}

In order to ensure the objectiveness of the experiment, an English proficiency test is taken by students of the two classes before the experiments.

The test scores are subjected to Levine inspection, and t-test of the independent samples shows that the students' English proficiency level of two classes doesn't reach significant difference. Then, the two classes are designated as experimental class and control class respectively, the two classes were taught by the same teacher using different assessment methods. Formative assessment is used in the experimental class, while summative assessment is used in the control class.

\subsection{Research Results}

After one semester, an English proficiency test is taken by students of two classes. The average score of the control class is 64.363 , and the average score of the experiment class is 68.764 (see Table 1). The significance rate is $0.381>0.05$ from Levine test, and the significance rate of $t$ test (2-tailed) is $0.038<0.05$. As a result, the difference reached significant difference level (see Table 2). It can be said that after a semester, the English level of students in experimental class is

Table 1. Group statistics.

\begin{tabular}{ccccc}
\hline Class & N & Mean & Std. Deviation & Std. Error Mean \\
\hline Class 1 & 35 & 68.764 & 11.7672 & 0.5532 \\
Class 2 & 34 & 64.363 & 12.3894 & 0.5541 \\
\hline
\end{tabular}

Table 2. Independent samples test.

\begin{tabular}{ccccc}
\hline & $\mathrm{t}$ & Sig. (2-tailed) & Mean difference & Std. Error difference \\
\hline $\begin{array}{c}\text { Equal Variances } \\
\text { assumed }\end{array}$ & 0.038 & 0.0381 & 3.423 & 0.7564 \\
$\begin{array}{c}\text { Equal Variances } \\
\text { not assumed }\end{array}$ & 0.038 & 0.0381 & 3.423 & 0.7896 \\
\hline
\end{tabular}


significantly higher than that of students in the control class. Thus formative assessment can effectively improve the students' Business English level.

\section{Formative Assessment System of VR English Autonomous Learning}

\subsection{The Principles of Formative Assessment}

At least the following principles should be observed in implementing formative assessment in Business English teaching.

1) Be objective. Objective and realistic attitude should be employed while subjective assumption should be avoided.

2) Be comprehensive. Comprehensive assessment should be made from multiple aspects to avoid one-sidedness.

3) Be scientific. Employment of uniform standard and consideration of individual difference should both be practiced. Assessment methods and procedures should be performed in a flexible way, so that the assessment result reflects the real situation.

\subsection{Subjects of Assessment}

The subjects of assessment refer to people who implement the assessment. In traditional summative assessment, teachers act as the subjects of assessment. They assess the teaching objectives and students' academic performance by designing assessment content and formulating assessment standards. While in formative assessment, both teachers and students act as the subjects of assessment.

1) Student assessment. There are two kinds of student assessment: self-assessment and peer-assessment. In self-assessment, students evaluate their performance in the learning process and the result of learning. For example, when students finish a task in business letter writing, they make assessment of both the writing process and the result of the writing. Effective self-assessment can promote active and conscious reflection of their learning, so they will be aware of their strength and weakness. In this way, students learn to define learning objectives, set learning pace and check the progress they have made at any time. Peer-assessment refers to the assessment among peers concerning writing process and result. For example, students evaluate each other's cooperative performance in the process of completing a task in business writing and the result of it. The practice of peer-assessment can enhance students' communication skills and collaboration skills. Meanwhile, they can learn from each other and make up for each other's deficiencies.

2) Teacher assessment. Teachers act as instructor, demonstrator and supervisor in the process of formative assessment and play an important role in monitoring students' self-assessment and peer-assessment. And they mark students' homework and give appropriate comments on them. In addition, the teacher should tell the assessment result to students in time so that students can revise their homework according to teacher's comments. 


\subsection{Assessment Content}

The assessment content of formative assessment for Business English teaching, include behavioral performance assessment and result assessment [8]. The traditional summative assessment only focuses on the assessment of the finished project assigned to students. Teachers make summative assessment of the content, organization and the use of language in students' writing, etc. While in formative assessment, the content of assessment for both teachers and students doesn't limit to only students' projects any longer but also includes performance students showed in the process of completing the assigned project.

1) Behavioral performance assessment. The formative and developmental feature of formative assessment is embodied in the assessment of students' behavioral performance in the process of Business English learning. For example, teachers and students can make assessment of the specific behavior of students in the process of learning such as their performance in class and their study motivation, and their positive engagement in group work, etc.

2) Project assessment. Similar to summative assessment, formative assessment also includes the assessment of students' finished projects such as the content and organization of their writing and the level of language proficiency.

Teachers should assess students writing on an integrated basis of their behavioral performance and finished project instead of focusing on one aspect only.

\subsection{Assessment Tools}

1) Teachers' observation records. In Business English teaching, we practiced the task-based approach which requires students to learn and practice English in the process of completing the learning tasks. Teacher classroom observation is the basis for evaluating students' learning performance and skills. Teacher observation records include: class participation (frequency, degree, and effect), tasks fulfillment (name, degree of difficulty, accomplishment quality, and degree of diligence), midterm feedback (problems, solutions, and approach), test results (times, achievements, and feedback), group work performance, etc. It describes student's performance in group activities mainly from two major aspects. One is student performance records in group activities; another is classroom performance rating.

In addition, the teacher observation records also include network communication (BBS, email, etc) and Internet surfing records, etc. For example, a teacher uploads a business video onto the Internet and requires students to watch. If students watch it online, a record is left, including the student's name, time, and the duration. Students can exchange with teacher about learning difficulties by BBS or by E-mail .All online activities leave records that become important facts for assessment.

2) Portfolio Assessment. Portfolios is a purposeful collections of any aspects of students work that tell the story of their achievements, skills, efforts, abilities, contributions and learning process to a particular class. In Business English learning, students are required to prepare a file folder, a small cardboard box, a sec- 
tion of a file drawer, or some other such receptacle. And in it, students can put their notes, diary, group-based project plan, lists of books that have read, essay, photos, tapes, etc. to form their portfolios. Additionally, as to the web-based autonomous learning, portfolio includes the online records in Business English autonomous learning system, such as the fulfillment of network task, teacher's comment, and simulation test scores. The functions of Portfolio assessment are as follows: first, it provides evidence to evaluate the degree of efforts, progression, and accomplishment students made in the learning process; second, students can make reflection on their study according to portfolio. Third, it can cultivate the ability of students to manage their affairs and self-study.

3) Assessment of learning effect. The assessment of learning effect is divided into three parts: the first part is the assessment of a student portfolio. It consists of self-assessment, peer assessment and teacher assessment. The second part is teacher assessment based on observation records. The third part consists of the quizzes and the final examination. Therefore, learning effect assessment is both an integral part of the assessment system, and the conclusion of formative assessment.

4) Other assessment tools. In addition to the assessment tools mentioned above, some other assessment tools are used in Business English, such as Journals and interviews. Journals and interviews are used to collect information about teaching and learning processes, about students' educational backgrounds and experiences, their attitudes, goals, likes and dislikes.

\section{Conclusion}

Formative assessment, as an inseparable part of teaching and learning process, gives the whole situation of student progress, and provides students' feedback to consolidate learning, which helps teachers know about student learning and determine the next step of teaching plan and student's study plan. Based on the VR teaching, formative assessment promotes the enthusiasm of students' autonomous learning and improves their business English proficiency and application ability. The establishment of formative assessment system can boost student involvement in learning, which stimulates the students' learning initiative and interest, and can cultivate students' autonomous learning ability.

\section{Acknowledgements}

This research was supported by Virtual Simulation Experiment Teaching Project of Zhejiang Province and Project of Demonstration Course of Zhejiang Yuexiu University of Foreign Languages (No. SZ1905).

\section{Conflicts of Interest}

The author declares no conflicts of interest.

\section{References}

[1] Cronbach, L.J. (2019) Designing Evaluations of Educational and Social Programs. 
Jossey-Bass, San Francisco.

[2] Jiang, H.m. (2018) The Application of WeChat in College English Teaching. Shuinde Vocational College, 6, 52-54.

[3] Lynch, B.K. (2011) Language Program Evaluation: Theory and Practice. Shanghai Foreign Language Education Press, Shanghai.

[4] Mackay, R. and Palmer, J.D. (1991) Language for Specific Purposes. Program Design and Evaluation. Newbury House, Rowley, Mass.

[5] Scriven, M. (2021) Prose and Cons about Goal-Free Evaluation. Evaluation Comment. The Journal of Educational Evaluation, 3, 1-7.

[6] Stake, R.E. (2009) A Theoretical Statement of Responsive Evaluation. Studies in Educational Evaluation, 2, 19-22. https://doi.org/10.1016/0191-491X(76)90004-3

[7] Stufflebeam, D.L. (2017) A Standards-Based Perspective on Evaluation. Advances in Program Evaluation, 3, 61-88.

[8] Weiss, C. (2016) Using Research in the Policy Process: Potential and Constraints. Policy Studies Journal, 4, 224-228.

https://doi.org/10.1111/j.1541-0072.1976.tb01557.x 